\title{
THE FINALITY OF A JUDGMENT AS A REQUIREMENT FOR CIVIL APPEALS IN GERMANY
}

\author{
HERBERT BERNSTEIN*
}

I

\author{
Introduction: An Overview of the German ${ }^{1}$ Court System
}

\section{A. The Court Hierarchies}

The Constitution of the Federal Republic of Germany, the Basic Law of 1949,2 provides for five different hierarchies of courts. In addition to the so-called ordinary courts with jurisdiction in civil and criminal cases, there are labor courts, social security courts, administrative courts, and tax courts. ${ }^{3}$ All of these court hierarchies have at their apex a federal court of last resort. ${ }^{4}$ The tax courts form a two-tiered system; all other court hierarchies comprise a three-tiered system.

In German legal terminology only the courts of last resort are "federal" courts, whereas the courts below this level are courts of the Länder (the ten states of the Federal Republic and Berlin). ${ }^{5}$ The rules determining the organization and the procedure of these courts, however, are embodied in federal statutes. ${ }^{6}$ With minor exceptions, the Länder have no original legislative power in this field. ${ }^{7}$ Their responsibility extends virtually exclusively to the implementation of the organizational and procedural statutes enacted by the federal legislature.

The Länder, however, do have authority to determine the number and the

Copyright (C) 1984 by Law and Contemporary Problems

* Professor of Law, Duke University.

1. Throughout this article the words "German" and "Germany" refer to the Federal Republic of Germany, unless the context indicates that the reference is to Germany before its partition after World War II.

2. GRundGeset 2 [GG], 1949 Bundesgesetzblatt [GB1] I 1.

3. Id. art. $95(1)$.

4. Id.

5. Id. arts. $23,95(1)$

6. The organization of the ordinary courts is based upon the Gerichtsverfassungsgesetz [BGVER rG] (first enacted in 1877, most recently consolidated on May 9, 1975, 1975 BGB 1 I 1077). Their procedure is governed by the Zivilprozessordnung [ZPO] (first enacted in 1877, consolidated on September 12, 1950, $1950 \mathrm{BGB} 1$ 533). The ZPO is sometimes referred to in the text and footnotes as the Code of Civil Procedure.

For surveys and discussions in English of German civil procedure, see Kaplan, Civil Procedure-Reflections on the Comparison of Systems, 9 Burralo L. REv. 409 (1960); Kaplan, von Mehren \& Schaefer, Phases of German Civil Procedure (pts. 1-2), 71 HaRv. L. REv. 1193, 1443 (1958); Meador, An Appellale Court Dilemma and a Solution through Subject Matter Organization, 16 J.L. RerOrm 471 (1983); Meador, Appellate Subject Maller Organization: The German Design from an American Perspective, 5 Hastings INT'L \& CoMP. L. REV. 27 (1981).

7. GG art. 74(1). 
territorial scope of judicial districts within their respective borders, as well as the number of judgeships assigned to the various courts. The Länder are also exclusively responsible for the appointment of judges in their territories, and they must carry the financial burdens of their judiciary. ${ }^{8}$ On the other hand, the appointment of judges to the federal courts of last resort is exclusively within the federal power. ${ }^{9}$ These judges are ordinarily appointed from intermediate appellate courts or, in the tax court system, from the courts of first instance.

\section{B. The Ordinary Courts}

The foregoing outline suggests that under the German system the subject matter jurisdiction of the so-called ordinary courts in civil cases is much more limited than in the United States. Cases involving governmental activities generally must be litigated in one of the specialized courts (administrative courts or tax courts). In addition, disputes arising from, or in connection with, employment contracts, along with collective labor controversies, are within the jurisdiction of the labor courts. ${ }^{10}$ This leaves the ordinary courts in civil cases an area of jurisdiction which is in essence restricted to private law disputes involving private litigants. ${ }^{11}$ Of course the government, state or federal, can be a party to such truly private law disputes if it acted in a nongovernmental capacity, for instance, as the owner of a building entering into an agreement with a contractor. Also, for historical reasons, the ordinary courts have jurisdiction in cases of monetary claims resulting from sovereign acts of the government, such as tort liability for injurious acts, ${ }^{12}$ or compensation for a taking of property by the government. ${ }^{13}$ Finally, there is a very limited number of precisely defined instances-in the area of antitrust law, for example-where a litigant challenging an act of the government must bring his case before an ordinary court rather than one of the specialized courts. ${ }^{14}$

The large majority of the issues litigated in civil cases under the German system, however, involve private interests and legal rules pertaining to such interests. It is against this background that the following study will attempt to analyze the final judgment rule in appellate cases within the German system. The rule, its application, and its exceptions will be studied only in the context of civil cases. Its application to criminal cases, as well as to cases litigated in the specialized courts, is beyond the scope of this article.

8. The status of judges, however, is subject to federal law. See Deutsches Richtergesetz, 1972 BGB1 I 713. It is also true that the vast majority of substantive law to be applied by the courts, especially in civil cases, is federal, not state, law; see Meador, supra note 6, at 29-30.

9. GG art. 95(2).

10. Arbeitsgerichtsgesetz $\S 2,1979$ BGB 1 I 853.

11. GVERFG $\S 13$ provides that the ordinary courts have jurisdiction over "civil controversies" (bürgerliche Rechtsstreitigkeiten).

12. GG art. 34 .

13. Id. art. 14(3).

14. Gesetz gegen Wettbewerbsbeschränkungen $\S \S 63(4), 73(1), 1980$ BGB 1 I 1761 .. 


\section{C. "Noncontentious" and Domestic Matters}

Germany, like many other civil law countries, has a tradition of distinguishing, within the realm of private law disputes, two categories of cases: "contentious matters" and "noncontentious matters." The various noncontentious matters are always designated as such in the legislation pertaining to them. Examples include cases involving probate, ${ }^{15}$ the commercial register, ${ }^{16}$ and guardianship. ${ }^{17}$ The procedure, including the appellate procedure, in these cases is subject to special statutory rules, ${ }^{18}$ which will not be discussed in this article.

Also excluded from the subsequent discussion are cases involving domestic relations in the broadest sense of the term. Since 1977, disputes of this description have been assigned to family courts within the hierarchy of the ordinary courts. ${ }^{19}$ Not unlike those divisions of these courts handling noncontentious matters, family courts are subject to procedural rules largely different from those applicable to civil cases in general. ${ }^{20}$

\section{II}

\section{The Various Modes of Review}

\section{A. Revision}

As pointed out above, only the highest court of each of the five German court hierarchies is a federal court. The name of the federal court for criminal and civil cases is Bundesgerichtshof; 21 it will be referred to in this article by the abbreviation commonly used in Germany, $B G H$.

An appeal to the $B G H$, due to its different attributes, must be distinguished from an appeal to an intermediate appellate court and is for this reason designated by a special term (Revision). The term used for first-level appeals (Berufung) is the literal counterpart of the English term. A Revision to the $B G H$ lies from final judgments of an intermediate appellate court, ${ }^{22}$ known as an Oberlandesgericht $(O L G) .{ }^{23}$ In exceptional cases, a Revision to the $B G H$ can also be taken from a final judgment of a court of first instance, called a Landgericht $(L G) .{ }^{24}$ Since such an appeal, "leaping" over the $O L G$ and therefore termed Sprung-Revision ("leap appeal"), requires consent by the appellee and is subject to further restrictive rules, ${ }^{25}$ it is very rarely attempted and will not be discussed in the remainder of this article.

The characteristics of an appeal to the $B G H$ are similar to those of an appeal in this country. The purpose of the appeal is to correct errors of law and not errors of

15. BÜRGERliches Geset'zbuGh [BGB] $\S 2260$.

16. Gesetz über Angelegenheiten der freiwilligen Gerichtsbarkeit [FGG] § 1251898 Reichsgesetzblatt [RGB1] 771 .

17. Id. $\S 35$.

18. See supra notes $15-17$.

19. GVERFG § $23 \mathrm{~b}$.

20. Id: ZPO $\$ \S 606(1), 62$ la-f.

21. GG art. $95(1)$; GVERFG $\$ \S 123-40$.

22. ZPO $\$ 545(1)$.

23. GVERFG $\S \S 115-20$.

24. Id. $\S \S 59-75$.

25. ZPO § $566 a$. 
fact. ${ }^{26}$ An appellant therefore can base his appeal solely on the ground that a rule of law, statutory or otherwise, was not applied or was incorrectly applied. ${ }^{27}$ In addition, the error of law must have affected the outcome of the case and have prejudiced the appellant ${ }^{28}$ In certain instances, there is an irrebuttable statutory presumption of a prejudicial effect resulting from a violation of procedural rules. ${ }^{29}$ Such a presumption governs, for example, in the case of noncompliance with rules concerning the composition or the jurisdiction of the court below.

Until fairly recently, an appeal to the $B G H$ was a matter of right in many cases. The almost universal problem of overcrowded dockets, however, has led to gradual legislative restrictions of this right. Under the present law, a Revision is ordinarily possible only if the $O L G$ has expressly allowed it in its judgment. ${ }^{30}$ The $O L G$ is bound to grant permission to appeal if the case is of "fundamental significance" or if the $O L G$ based its judgment on an opinion which conflicts with that laid down in a case previously decided by the $B G H$ or by a superpanel of the federal courts in charge of resolving conflicts among these highest courts. ${ }^{31}$ The decision by an $O L G$ to allow the appeal on one of these grounds is binding upon the $B G H .^{32}$

Irrespective of permission to appeal granted by the $O L G$, a party can always file an appeal with the $B G H$ if the amount in controversy on review is more than 40,000 Deutsche Mark (DM) (currently the equivalent of less than $\$ 16,000$ ). ${ }^{33}$ The $B G H$, however, need not accept the case for a decision on the merits. ${ }^{34}$ Rather, it can disallow the appeal, provided two-thirds of the judges competent to hear the appeal agree that the case is devoid of "fundamental significance." 35 The appellant is not entitled to an oral hearing before his appeal is disallowed. ${ }^{36}$ An absolute right to appeal to the $B G H$ continues to exist in cases where an $O L G$ has dismissed for lack of jurisdiction a (first) appeal from a judgment of a court of first instance. ${ }^{37}$

In summary, the appellate procedure at the highest level under the present German system is affected by the ability of the $B G H$ to control its caseload. To be sure, on its face, the exercise of this control does not involve discretion as broad as that exercised by the U.S. Supreme Court in granting or denying certiorari. Still, the determination that a case lacks "fundamental significance," while strictly speaking a decision on a question of law, allows the $B G H$ to apply stricter or more

26. Id. $\S 549(1)$.

27. Id. $\S \S 549-50$.

28. Id. $\S 549(1)$ (requiring that the challenged decision be "based" (beruht) on the "violation" (Verletzung) of a rule of law).

29. Id. $\S 551$.

30. Id. $\S 546(1)$.

31. Id.

32. Id.

33. Id.

34. Id. $\$ 554 \mathrm{~b}$.

35. Id. $\S 554 \mathrm{~b}(1)$, (2); see also GVERFG § 139(1) (providing that five judges shall form a $B G H$ panel). This rule, enacted in 1975, was attacked on constitutional grounds. The two panels of the Federal Constitutional Court could not agree on the issue; the full court eventually upheld the enactment interpreting it so as not to authorize an a limine denial of review in cases where the appeal has a chance to prevail. See Judgment of June 11, 1980, 54 Bundesverfassungsgericht [BVerfG] 277 (1980).

36. ZPO \& $554 \mathrm{~b}(3)$.

37. Id. $\S 547$. 
lenient standards of scrutiny, in keeping with the demands of the court's docket. Strangely, however, the responsibility for the exercise of this control is divided among the intermediate appellate courts and the $B C H$, as explained above. ${ }^{38}$ The purpose of entrusting a share of this responsibility to the $O L G$ is to reduce the burden of summary review for the $B G H$; however, the device is questionable on due process grounds.

\section{B. Berufung}

Unlike a Revision to the $B G H$, an appeal (Berufung) to an $O L G$ is not limited to a review of errors of law. ${ }^{39}$ Rather, it is designed to rectify the result reached by the court below (the $L G$ ) on questions of fact as well as on points of law. ${ }^{40}$ To allow a review and reversal by the $O L G$ on factual grounds, the $L G$ need not even have committed an error of fact in the strict sense. This is so because the appellant (and also the appellee) is entitled to present new facts and new evidence in the intermediate appellate court. ${ }^{41}$ This principle is subject to certain restrictions, so as to discourage dilatory tactics, ${ }^{42}$ but by and large the procedure in the $O L G$ amounts to trial de novo. ${ }^{43}$ The $O L G$ has the record of the $L G$ before it, since this record is passed on to the $O L G$ immediately after a notice of appeal has been filed. ${ }^{44}$ In considering questions of fact the $O L G$ is, however, in no respect bound by the record. It is not limited by the record; it can consider new facts and/or new evidence if presented. In fact, the $O L G$ has the power, if appropriate, to rehear evidence already in the record. ${ }^{45}$

The civil panels of the $O L G$ are composed of three judges, ${ }^{46}$ and the court's appellate jurisdiction extends to all cases in which the $L G$ has rendered a final judgment as a court of first instance. This jurisdiction is limited only to the extent that in a pecuniary controversy the amount involved on review must exceed 700 DM (currently the equivalent of less than $\$ 300){ }^{47}$ In nonpecuniary matters, the monetary requirement is by definition inapplicable.

The $O L G$ does not have appellate jurisdiction over decisions by the $L G$ where the $L G$ is not a court of first instance. In a group of cases, defined by statute, the $L G$ functions not as a court of first instance, but as an appellate court. ${ }^{48}$ The $L G$ has appellate jurisdiction in cases which are within the trial court jurisdiction of the Amtsgericht, $(A G) .{ }^{49}$ This court has exclusive subject matter jurisdiction over several types of specific controversies. Among them is litigation between a

38. Compare ZPO $\$ 546$ with ZPO $\S 554 \mathrm{~b}$ (lower court must allow appeal in certain cases, but higher court may dismiss appeal lodged at the party's discretion).

39. ZPO $\S 519(1)$, (3) (requiring grounds for the appeal without confining the grounds to errors of law).

40. Id. $\$ 537$.

41. Id. $\S 519(3)(2)$.

42. Id. $\$ \S 527-31$.

43. Id. $\$ \S 523,525$

44. Id. $\$ 544$.

45. Id. $\S \S 523,525$.

46. GVERFG $\$ 122$

47. ZPO $\$ 511$.

48. GVERFG $\$ 72$.

49. ZPO $\$ 511$; GVERFG $\S 72$. 
landlord and tenant involving the rental of rooms, apartments, and houses for dwelling purposes (Wohnraummiete), in which the right to possession, repossession, or use of the property, or to a renewal of the lease (based on a statutory right under certain Civil Code sections) is in issue. ${ }^{50}$ In addition, the $A G$ has concurrent jurisdiction in matters not exceeding an amount in controversy of 7,000 DM (currently the equivalent of less than $\$ 3,000){ }^{51}$ Cases litigated in the $A G$ before a single judge can be appealed to the $L G$, subject again to a monetary minimum requirement of $700 \mathrm{DM}$ in pecuniary matters, and without such a restriction in nonpecuniary matters. ${ }^{52}$

As an appellate court, as well as in its role as a court of first instance, the $L G$ sits in panels of three judges. ${ }^{53}$ The appellate procedure in the $L G$ follows the same rules applicable to an appeal to the $O L G^{54}$ It is essential, however, to emphasize that judgments rendered by the $L G$ on appeal from the $A G$, unlike judgments of the $O L G$, are not subject to any further review in an ordinary court. ${ }^{55}$ This follows from two rules previously stated: (1) An appeal to the $O L G$ lies only from final judgments rendered by the $L G$ as a court of first instance; ${ }^{56}$ (2) An appeal to the $B G H$ by way of Revision is available only from final judgments of an $O L G^{57}$ or, by way of Sprung-Revision, from a final judgment of an $L G$ sitting as a court of first instance. ${ }^{58}$

The restriction imposed on the reviewability of final judgments of the $L G$ in cases originally litigated in the $A G$ is commonly justified as a consequence of the limited significance and weight of these controversies. An interesting debate with some bearing on the final judgment principle arose in this regard when it was recently found that inconsistencies in the case law among various $L G$, and even within one $L G$, affected a large number of people and were felt to be intolerable by substantial segments of the public. Even though this debate did not prompt the legislature to make appealable any appellate judgments of the $L G$, a different method of review, certification of a question of law to a higher court, was established. ${ }^{59}$ This means of resorting to the resources and authority of a higher tribunal or of a coordinate superpanel is a feature of the German court system which will be analyzed separately below. ${ }^{60}$

\footnotetext{
50. GVERFG $\S 23(2)(a)$.

51. Id. $\S 23(1)$.

52. ZPO $\S \$ 511-511 \mathrm{a}(1)$.

53. GVERFG $\$ 75$.

54. ZPO $\S \S 511-544$ apply indiscriminately to any appeal from a judgment rendered by a court of first instance.

55. The only possible means of review is through a constitutional complaint to the Federal Constitutional Court, pursuant to $\mathrm{GG}$ art. 93(1)(4)(a). This article authorizes review where a litigant's constitutional right has been violated by official authority, a rare occurrence in a civil case.

56. ZPO $\$ 511$; see supra text accompanying notes 46-48.

57. Id. $\$ 545$; see supra tcxt accompanying notes $22-23$.

58. Id. $\$ 50 \mathrm{uad}$, see ryhra text accompanying notes 24-25.

59. Law of June 5, 1980, 1980 BGB 1 | 657, amending Drittes Gesetz zur Änderung mietrechtlicher Vorschriften of Dec. 21, 1967.

60. See infra text accompanying notes 71-80.
} 


\section{Beschwerde}

The Beschwerde, a further method of review under German law, will be referred to, for lack of a more satisfactory translation, as "limited appeal."61 It is available in certain specifically designated instances and in all cases in which a motion concerning a matter of procedure is denied, provided the law does not require the judge to grant an oral hearing to rule on this motion. ${ }^{62}$ With only a few exceptions, decisions of the $O L G$ are not subject to a limited appeal, whereas most decisions rendered by an $A G$ or by an $L G$ can be challenged in this fashion. Details must be discussed below, because viewed from the perspective of the final judgment rule, the availability of a limited appeal is frequently tantamount to an exception to this rule. Since the Beschwerde is sometimes the means of effecting the review of a final decision, however, it would be entirely misleading to translate the German term as "interlocutory appeal."

There are two different kinds of limited appeal. The "simple" (einfache) limited appeal can be filed any time after the challenged decision is rendered; no running of a specific period of time precludes the use of this remedy. ${ }^{63}$ On the other hand, the "prompt" (sofortige) limited appeal must be filed within two weeks after the decision has been served upon the aggrieved party or, in certain cases, after it has been announced in open court. ${ }^{64}$

A simple limited appeal ordinarily must be filed in the court whose decision is attacked; only in urgent cases can it be filed in the higher court. ${ }^{65}$ The policy behind this rule is that the court below has the power and should, if possible, be given an opportunity to reconsider and vacate its decision. ${ }^{66}$ Only if the court concludes that there is no reason to comply with the appellant's demand will the case proceed to the higher court. ${ }^{67}$

In cases where the law provides for a prompt limited appeal, the court whose decision is challenged has no authority to reconsider and vacate. ${ }^{68}$ The power to decide upon the limited appeal is vested exclusively in the higher court. ${ }^{69}$ The filing can be effected alternatively in this court or in the court below. ${ }^{70}$

\section{Vorlageverfahren}

A study of the final judgment rule under German law would be incomplete without an analysis of the various certification procedures (Vorlageverfahren), mentioned above in connection with the virtually absolute finality of appellate judgments of the $L G .^{71}$ Such procedures are a significant element in the plethora of

61. This is the translation adopted in Kaplan, von Mehren \& Schaefer, supra note 6, at 1445.

62. ZPO $\$ 567(1)$.

63. See id. $\S 567$ (defining the prerequisites of a simple limited appeal without setting a time limit).

64. Id. $\$ 577(2)$.

65. Id. $\S 569(1)$.

66. Id. $\$ 571$

67. Id.

68. Id. $\S 577(3)$.

69. Id.

70. Id. $\S 577(2)$.

71. See supra text accompanying note 59. 
methods of review in the German legal system.

In some instances, certification of a legal question serves as a substitute for an appeal. More specifically, where the jurisdiction of a judicial body cannot be invoked by the parties to a case for purposes of review, German law sometimes provides for the certification of a legal question to this body, a higher court, or a superpanel of the court in which the case is pending. ${ }^{72}$ In other instances, certification of a question of law is required, or at least permitted, while the case is still being litigated in a lower court, even though the final judgment of that court will be subject to review upon appeal. ${ }^{73}$

To illustrate the first variety of certification procedure, the recent debate over the nonappealability of appellate $L G$ judgments is instructive. This debate unfolded in the media and among lawyers over disputes concerning the rental of rooms, apartments, and houses for dwelling purposes (Wohnraummiete). Without regard to the amount in controversy, cases in this area are subject to the exclusive jurisdiction of the $A G$ and therefore reviewable only on appeal to the $L G$. Such appeal is limited further to cases involving a right to possession, repossession, use of the property, or to renewal of the lease, where the right is derived from certain statutory provisions. ${ }^{74}$ To counteract the public dissatisfaction that developed as a result of irremediable divergencies in the case law (irremediable because of the unavailability of appeal beyond the $L G$ ), the legislature resorted to the creation of a new device to remedy these conflicts. It did so, however, without opening up new avenues of appeal.

This device, denominated Rechtsentscheid, is the most recent brand of the certification procedure. It leads to a decision of a question of law by an $O L G$-even by the $B G H$ upon judicial initiative while the case is still before the $L G$ on appeal and has not yet been disposed of by a final judgment. ${ }^{75}$ The $L G$ panel in a dispute involving, for instance, the rental of rooms for dwelling purposes is now required by statute to certify a question of law to the $O L G$ if it intends to deviate with respect to that question from a decision of the $B G H$ or of an $O L G$, or if the legal question is of "fundamental significance" and has not yet been decided by Rechlsentscheid. ${ }^{76}$ Before certifying the question of law to the court above, the $L G$ must ask the parties for written statements of their opinion on this question and is required to attach their statements to its request for a Rechtsentscheid. ${ }^{77}$ Should the $O L G$ in turn conclude that it intends to depart from a decision of the $B G H$ or another $O L G$, it must certify the question of law to the $B G H .^{78}$

The standard of "fundamental significance," which is used to control the caseload of the $B G H$ in the area of Revision (appeal), is thus also used to obtain a decision from an $O L G$ in certain cases which are not within its appellate jurisdiction. This standard can be invoked for the purposes of avoiding or resolving

72. FGG § 28; GVERFG § 136.

73. GG art. $100(1)$, (2).

74. GVERFG § 23(2)(a).

75. Law of June 5, 1980, art. III(1), 1980 BGBI I 657; see also supra text accompanying note 59.

76. Law of June 5, 1980, art. III(I), 1980 BGB 1 I 657.

77. Id.

78. Id. 
conflicts in the case law among various $L G$ or within one $L G$. It was the very purpose of the statutory amendment to accomplish this result.

Furthermore, the Rechisentscheid constitutes an innovation in the area into which it has been introduced. In response to public demands, it makes available for the first time the resources of higher courts in a social arena and in a field of law which has traditionally been viewed as not deserving or not requiring these resources. This is certainly a remarkable development. In the context of this article, however, it is probably more noteworthy that the technique which the legislature employed for the implementation of its policy is by no means novel. The certification of a question of law to a particular court or a particular panel of a court by a judge prior to his rendering a final decision in the case before him is frequently mandated by rules of procedure in Germany, ${ }^{79}$ and, to some extent, by the Treaty of Rome in the European Community. ${ }^{80}$

The policy underlying all of these rules is in certain respects the direct opposite of the policy which is sometimes invoked to justify the final judgment principle. An adoption of this principle appears to proceed primarily on the premise that the resources of a higher court should not be tapped until after the case is completely disposed of at the lower court level and all the resources of the lower court have been brought to bear on the case. In contrast, a certification procedure seems at least partly to rest on the assumption that it is wasteful and sometimes beyond the authority of a lower court to decide questions of law which require a uniform and authoritative pronouncement at a higher level before the individual case can properly and most efficiently be decided.

\section{III}

\section{The Final Judgment Rule}

\section{A. The Basic Approach}

With respect to the finality of judgments as a requirement for civil appeals, the German law at first glance appears to be clearly and succinctly stated in two sections of the Code of Civil Procedure. According to section 545 of that Code, a Revision to the $B G H$ lies from final judgments rendered by an $O L G$ as an appellate court. ${ }^{81}$ To this the Code adds that Revision can be had according to certain enumerated provisions. ${ }^{82}$ The subsequent Code sections, however, do not make inroads on the principle of finality stated in section 545; rather, they limit the power to attack a judgment by way of Revision even where the judgment is final. ${ }^{83}$

Using language very similar to that of section 545, the Code of Civil Procedure provides in section 511 that a first appeal (Berufung) is available from final

79. See, e.g., FGG $\S 28$; GG art. 100(1).

80. See Treaty of Rome, Mar. 25, 1957, art. 177, 298 U.N.T.S. 3, 76-77 (establishing the European Economic Community) (effective Jan. 1, 1958).

81. ZPO $\$ 545(1)$.

82. Id.

83. See, e.g., id. $\S \S 545(1), 546$. Some of these limitations were discussed in Part II, supra. Others do not warrant discussion since they are not directly relevant to the issue of finality and do not contribute significantly to an enhanced understanding of the framework of German appellate review. 
judgments rendered by a court of first instance. ${ }^{84}$ By virtue of this rule, Berufung can be used to attack a judgment of the $A G$ by means of review by the $L G$, or to attack a judgment by the $L G$ on review by the $O L G$, provided the $L G$ exercised its jurisdiction as a court of first instance, and not as an appellate court. ${ }^{85}$ Even though section 511 , unlike section 545 , does not contain a proviso, the Code spells out the previously discussed restriction on the right to a first appeal in section $511 \mathrm{a}$, which is to the effect that in pecuniary matters there will be no Berufung unless the amount in controversy on review exceeds 700 DM. ${ }^{86}$

Neither of the two basic rules stating the German variant of the finality principle (that is, neither section 545, concerning Revision, nor section 511, applicable to Berufung) attempts to define the term "final judgment." Thus the impression of clarity and succintness created by these Code sections is somewhat deceptive. In fact, none of the rules relating to review of judicial decisions in sections 511 through 577 of the Code supplies anything even remotely resembling a definition of final judgment or an enumeration of the decisions appealable as final judgments.

Guidance appears elsewhere, in sections 300 through 329 of the Code of Civil Procedure, under the heading of Urteil (judgment). Section 300(1) directs the courts to render a final judgment, if "the controversy is ripe for final decision." " 7 It is tempting to conclude that a final decision in this sense and, consequently, a final judgment, is a decision which disposes of all the issues in controversy between all the parties to a particular case. Such a conclusion would be clearly erroneous, as can be gleaned from several other rules in sections 300 through 304 .

Immediately following the basic rule of section $300(1)$ which mandates a final judgment where a controversy is ripe for final decision, the Code provides in section $300(2)$ that, if cases were consolidated by the court for the purpose of simultaneous trial and decision, and only one is ripe for final decision, the court must render a final judgment. ${ }^{88}$ It follows from this provision that in cases of multiple parties and/or multiple claims which were originally involved in separate cases, but were then consolidated by the court under section 147 of the Code of Civil Procedure, a decision disposing of less than all the consolidated cases is a final judgment and such decision must be made, with no discretion granted to the court, as soon as one or more of the consolidated cases is ripe for decision. ${ }^{89}$

Going one step further, section 301 (1) provides that a final judgment ordinarily must be rendered if only one of several claims, only a (separable) part of plaintiff's claim, or, if a counterclaim was filed by the defendant, only the claim or the counterclaim (but not both) is ripe for final decision. ${ }^{90}$ The Code expressly terms this

84. Id. $\S 511$.

85. See supra text accompanying notes $48-58$.

86. ZPO $\$ 511$ a.

87. Id. $\S 300(1)$.

88. Id. $\S 300(2)$.

89. ZPO $\S 300(1)$ unambiguously provides that "the court must render final judgment" where the case is ripe (emphasis supplied). Section $300(2)$ provides, in equally clear terms, that when one of several consolidated cases is ripe for decision, section $300(1)$ applies as well.

90. The term "counterclaim" is used here the same way as in the Federal Rules of Civil Procedure in the United States. The corresponding German term is Widerklage. 
kind of final judgment, a Teilurteil, which in English would be a "partial judgment" (as distinguished, obviously, not from an impartial, but from a complete judgment). The Code further provides in section 301(2) that the court need not render a Teilurteil if in view of the circumstances it would be inappropriate. ${ }^{91}$

Legal writers and courts try to clarify the terminology as well as the law itself by using the term Teil-Endurteil (partial final judgment) so as to dispel any possible doubt regarding the finality of the partial judgment under discussion. ${ }^{92}$ Their at tempt at clarification is entirely consistent with the language and the purpose of section 301. Obviously, this Code section is designed to allow and even to compel piecemeal adjudication and piecemeal appeals, subject only to the limited discretion of the court to withhold its decision until the entire controversy can be decided and laid to rest. Partial judgments appear to be favored by the Code and are treated as final judgments with or without an express statement to that effect by the court.

\section{B. The Setoff Exception}

A similar policy emerges from section 302 of the German Code of Civil Procedure. This section deals not with a counterclaim, but with a setoff by the defendant and applies to situations where the claim underlying the setoff has "no legal connection" with the plaintiff's claim, as the Code phrases it, thereby expressing the converse of the principle of "connexity." 93 Typically, this means that defendant's alleged claim arises from a transaction or occurrence other than that on which plaintiff's claim is based. The Code provides in section 302(1) that under these circumstances the court may enter judgment for plaintiff, reserving the decision on the setoff if the proceedings are ripe for decision only on the plaintiff's claim. ${ }^{94}$ Furthermore, section 302(3) provides that such judgment "is to be regarded as a final judgment with respect to review and enforcement."95

While the rules in sections 300 and 301 pertaining to multiple parties, multiple claims, separable parts of a claim, and counterclaims can be viewed as instances of an application of the finality requirement ${ }^{96}$ the rule pertaining to setoffs in section 302 undeniably dispenses with that requirement. The plaintiff's claim does not exist if there is an effective setoff. At the time the court gives judgment for plaintiff on the basis of section 302(1), it is uncertain whether the setoff will be held to have

91. ZPO $\$ 301(2)$.

92. L. Rosenberg \& K.H. SCHWAB, ZivilprożesSRECHT, \& 55 II 2 (12th ed. 1977).

93. See Blomeyer, Types of Relief Available (Judicial Remedies) in 16 INTER NATIONAL ENCYCLOPEDIA OF COMPARATIVE LAW 4-128 (1982). In civil law systems the principle of "connexity" is generally understood to be a means of limiting the right to withhold performance because a counterclaim exists, or the right to exercise a setoff. For instance, BGB $\S 273$ permits the debtor to withhold performance if he has a claim arising from "the same legal relationship." On the other hand, BGB $\S 387$ allows a setoff to be used whenever two parties owe each other money or other fungible goods of the same character, regardless of whether the mutual claims arose from the same legal relationship. Against the backdrop of this substantive law rule, ZPO $\S 302$ enables the courts to engage in piecemeal adjudication where a setoff involves unrelated claims, or, in civil law terminology, where there is no "connexity" of the mutual claims.

94. ZPO § 302(1)

95. Id. $\S 302(3)$ (emphasis added).

96. The argument supporting this view is that with respect to, for instance, one of the parties or one of the claims, there is a disposition of the case which, to this extent, leaves nothing for the court to do. 
been effective. Therefore the court's judgment does not determine with finality that the plaintiff has a claim. Rather, the judgment in plaintiff's favor is a conditional one, as is clearly spelled out in section 302(4). This section provides that the case remains pending in the court once it has reserved its decision on the setoff, ${ }^{97}$ which, under section 302(2), it can be compelled to do, if necessary, by a motion to supplement its judgment in conformity with section 321 of the Code of Civil Procedure. ${ }^{98}$

Section 302(4) goes on to provide that the court must reverse its own prior judgment if, in the course of the subsequent proceedings, it finds that (because of an effective setoff) the plaintiff's claim(s) did not exist. ${ }^{99}$ Furthermore, by virtue of section 302(4) the defendant is entitled to damages if he suffers a loss as a consequence of an enforcement of the conditional judgment; ${ }^{100}$ these damages can be claimed as part of the pending case in the court which first rendered and then reversed the conditional judgment. ${ }^{101}$

The upshot of this in the present context is that section 302 of the German Code of Civil Procedure permits the defendant to appeal a nonfinal judgment on the basis of the legislative fiction that the judgment "is to be regarded" as final for review purposes. At the same time the defendant is allowed to proceed with his setoff defense in the first court. Rather complex and intriguing questions arise when the appeal is successful before the setoff issue is decided or, conversely, when the court below reverses its judgment while the appeal is still pending. These ramifications of an application by the courts of section 302 unfortunately cannot be pursued here.

\section{The Interlocutory Judgment Exception}

If an action is dismissed for lack of jurisdiction, improper venue, or similar procedural reasons unrelated to the merits of the case, the decision is ordinarily a final judgment under German law as well as U.S. law, since in the court's view it can dispose of nothing further. On the other hand, a court which considers a jurisdictional or a similar procedural defense unfounded, need not decide the issue before the merits of the case have been litigated. ${ }^{102}$ Should the court choose to render a judgment on all procedural and substantive issues after the case has been fully tried, there is again a final judgment under both legal systems.

The court may prefer to decide a procedural issue before all the issues have been fully litigated. The court's reason to opt for such strategy can be the preclusion of the parties from rearguing a matter which, in the court's view, has been sufficiently argued. Section 303 of the German Code of Civil Procedure enables

97. ZPO § 302(4).

98. Id. $\S \S 302(2), 321$.

99. Id. $\$ 302(4)$.

100. Id.

101. Id.

102. Id. $\S 303$. This section permits the court to decide an interlocutory dispute by an interlocutory judgment, but carefully avoids mandatory language. It states that the court can, (i.e., has the power to) render such judgment. The skillful drafting technique used in German codes clearly leaves it to the court's discretion whether to decide a jurisdictional issue separately or together with the merits of the case. 
the court to proceed in this fashion. It provides that a Zwischenstreit (a preliminary or collateral controversy) can be decided by Zwischenurteil (an interlocutory judgment) once it is ripe for decision. ${ }^{103}$ This applies to any preliminary or collateral controversy not directly involving the subject matter of the case-a line which, in cases where a party's duty to release documents is contested, for example, is sometimes difficult to draw. ${ }^{104}$ An interlocutory judgment based upon section 303 is not appealable, because it is not final. It lacks finality since it does not dispose of the case as such, either in its entirety or with respect to certain parties or certain claims or separable fragments of claims. ${ }^{105}$

Furthermore, section 303, unlike section 302, does not contain language reflecting the legislative fiction that the interlocutory judgment for purposes of review "is to be regarded" as a final judgment. ${ }^{106}$ Consequently, a party adversely affected by a judgment under section 303 must wait until after the case is disposed of by a second judgment which has the characteristics of a final judgment. Provided this judgment is appealable by that party, the appellate court ordinarily will have the power to review, together with the final judgment, all decisions preceding it in the court below. This rule applies to both a Revision (pursuant to section 548) and a Berufung (purusuant to section 512). ${ }^{107}$

Decisions which the Code of Civil Procedure expressly designates as being immune from any direct review, however, cannot be incidentally reviewed under sections 512 and 548. ${ }^{108}$ An illustration of this exception is a ruling of the court below permitting the plaintiff to amend or modify his complaint. ${ }^{109} \mathrm{By}$ contrast, section 303 does not expressly deny review. The consensus among courts and writers therefore supports the reviewability under sections 512 and 548 of interlocutory judgments based on section 303, as an incident to appellate review of a final judgment. ${ }^{110}$

\section{Id.}

104. Such duty may originate from substantive law. See, e.g., BGB $\S 810 ;$ ZPO $\S 422$. On the other hand, it may result from the course of litigation itself. See ZPO $\$ \$ 421,423-27$.

In this area, confusion on the part of litigants and the courts appears not infrequently to occur. Where a court renders the wrong kind of decision, the $B G H$ has held that a party is entitled to review if either the decision as rendered or the one which should have been rendered is reviewable. Judgment of June 20, 1977, BGH, 92 ZEITSCHRIrT yür ZIVILPROZESSRECHT 362 (1979); accord id. at 364-69, note P. Gottwald (and authors cited therein). This result is rationalized as the "most favorable treatment" (Meistbegunstigung) due the victim of a judicial mistake. See L. Rosenberg \& K.H. Schwab, supra note 92, § $133 \mathrm{II}$.

If, however, the court decides by interlocutory judgment an issue which must not be decided other than by final judgment, the $B G H$ allows no immediate appellate review. Judgment of October 18, 1951, 3 Bundesgerichtshof in Zivilsachen [BGHZ] 244 (1951); accord K. Tiedtke, Das unzulässige Zwischenurteil, 89 Zeitschrift für Zivilprozessrecht $64,74-75$ (1976). The court also denies any binding effect to such a judgment. Judgment of Feb. 5, 1953, 8 BGHZ 383 (1953).

105. Nonetheless, since the decision takes the form of a judgment and is not merely an order, it is binding upon the court. ZPO $\S 318$. This precludes any further arguments by the parties relating to the issue decided upon. See A. Baumbach, W. Lauterbach, J. Albers \& P. Hartmann, ZivilprozesSORDNUNG, $\S 303$ annot. 3 (40th ed. 1982) [hereinafter cited as BAUMBACH].

106. Compare ZPO § 303 with $\S 302$.

107. ZPO $\S 512,548$.

108. Each section contains a proviso to the effect that a decision preceding the final judgment may not be incidentally reviewed if it is not directly reviewable.

109. See ZPO §§ 263-64, 268. 762.

110. See BAUMBACH, supra note $105, \S 512$ annot. 1; L. ROSENBERG \& K.H. SCHWAB, supra note 92, at 
A different situation arises where an interlocutory judgment holding a complaint to be zulässig (admissible) is rendered pursuant to section 280 of the Code of Civil Procedure. ${ }^{111}$ Typically, such a judgment overrules a defense based on lack of personal or subject matter jurisdiction, lack of capacity on plaintiff's part, and the like. Section $280(1)$ of the Code empowers the court to conduct a special hearing to try such issues, pertaining to the so-called admissibility of the complaint. ${ }^{112}$ According to section 280(2), an interlocutory judgment on these issues "is to be regarded" as a final judgment for purposes of review. "13 With language identical with that in section 302 (dealing with setoffs), ${ }^{114}$ section $280(2)$ creates a fictional "finality" in order to make a particular kind of nonfinal judgment appealable. The policy underlying this preferred treatment of certain decisions by the Code appears to be a deliberate choice in favor of avoiding a possible waste of time, energy, and cost. The court below might expend such resources on the merits of the case unnecessarily, if the court above subsequently finds the first court had no jurisdiction or the complaint was for some other reason inadmissible.

In view of this policy, it would seem that the appealability of an interlocutory judgment on admissibility should not turn on whether the judgment was preceded by the special hearing on that issue allowed by section 280(1) of the Code. Even if the judgment was rendered after one or more hearings during which both the admissibility and the merits of the complaint were argued (and, possibly, evidence was taken), the judgment should be appealable on the basis of section 280(2). The prevailing view of German courts and witers supports this interpretation. ${ }^{115}$ Those favoring the minority view can argue that there is a close spatial connection between this rule and section 280(1) which provides for an optional special hearing on admissibility. This fact, however, seems to be outweighed by the policy consideration favoring conservation of judicial resources, coupled with the argument that the minority position allows the lower court to manipulate appealability by ordering or withholding a special hearing.

Undeniably, however, a certain degree of inconsistency can be found in section $280(2)$, just as in similar rules providing for review of nonfinal decisions. Such rules assume that early appellate control over the basic procedural correctness of the proceedings below is desirable in order to avoid expenditure of efforts and resources at the lower level which may later be rendered unnecessary by a reversal based on procedural defects. These rules can be fully effective in accomplishing their policy only if the case will not be litigated, and possibly terminated, in the lower court while the appellate court has the appeal before it. Should the lower court, after rendering the interlocutory decision in favor of plaintiff, continue to try the case while defendant appeals that decision, then the purported aim of avoiding wasted time, energy, and money is likely to be thwarted; the desired

111. ZPO \& 280 .

112. Id. $\S 280(1)$.

113. Id. $\S 280(2)$.

114. See supra note 95 and accompanying text.

115. See Judgment of Oct. 17, 1956, BGH, 1957 JuRISTENZerTUNG 95; L. RosenberG \& K.H. SCHWAB, supra note 92, $\$ 55$ III 2 (and authors cited therein). Contra 1957 JURISTENzeITUNG 96 annot. L. Rosenberg. 
savings will be lost, in part or entirely, depending on how and when the appellate court decides the issue.

Section 280(2) of the Code of Civil Procedure expressly enables the court whose interlocutory judgment on the admissibility of the complaint is appealed to order further hearings on the merits if so requested by motion. ${ }^{116}$ In the literature, it is pointed out that the plaintiff's motion should be granted only in cases of urgency or where the chances of the defendant's prevailing on appeal are minute. ${ }^{117}$ Obviously, this leaves much room for discretion by the lower court judge whose decision is attacked and who may have a natural inclination to attribute little weight to the appeal.

The court's order granting or denying plaintiff's motion for further hearings on the merits is itself subject, to some extent, to appellate review. The device of limited appeal, discussed more extensively later in this article, may be available by analogy to section 252 of the Code of Civil Procedure, which provides for limited appeal from a decision ordering or refusing to order a stay of the proceedings. ${ }^{118}$ Thus, the appellate court has some control over the further proceedings below during the pendency of the interlocutory appeal. This applies only so long as the interlocutory appeal is taken from a decision of the $A G$ or the $L G$; limited appeal can be used to attack certain decisions of these courts but, according to section 567(3) of the Code of Civil Procedure, it generally cannot be used to appeal decision of the $O L G{ }^{119}$ Consequently, an $O L G$ which has rendered an interlocutory judgment holding the complaint to be admissible and whose judgment is attacked by Revision to the $B G H$ is not subject to review of its decision to grant the plaintiff's motion for further hearings on the merits.

This is presumably a rare case, primarily because the $O L G$ is an appellate court; in civil cases it never functions as a court of first instance. ${ }^{120}$ Therefore, when a case reaches the $O L G$, it has already been litigated in the court below. If the lower court held the complaint to be inadmissible and the $O L G$ reaches the same conclusion, it must render a final judgment to that effect. ${ }^{121}$ On the other hand, if the $O L G$ considers the complaint to be admissible after it was held to be inadmissible by the $L G$, the appellate court must reverse and remand the case. ${ }^{122}$

The $O L G$ would itself grant an interlocutory judgment on the admissibility

116. ZPO § 280(2).

117. See R. ZÖLLER, ZIVILPROZLSSORDNUNG, $\$ 280$ annot. III (12th ed. 1979).

118. The rule in section 252 goes further than the more general rule on limited appeals stated in section 567 , see supra notes 62,63 , and accompanying text; infra $\mathrm{pp}$. - . While section 567 permits a party to appeal an order, not based on a mandatory oral hearing, which denies a motion concerning a matter of procedure, section 252 makes a limited appeal available not only against an order denying, but also against an order granting a stay. By analogy, this applies to an order granting or denying plaintiff's motion for further hearings after an interlocutory judgment pursuant to section 280(2) on the admissibility of the complaint was rendered. See BaUmbaCH, supra note $105, \S 280$ annot. 3 B a (relying on Judgment of Dec. 3, 1970, OLG Karlsruhe, 1971 NEUE JURISTISCHE WOChENSCHRItT 662 and authorities cited therein). Conira, Judgment of Feb. 18, 1974, OLG Munich, 1974 NeUE JURISTISChe WOChensChRIrT 1514; R. ZöLLER, supra note $117, \S 280$ annot. III.

119. ZPO § $567(3)$.

120. GVERFG § 119.

121. ZPO $\S 300$.

122. Id. $\S 538(1),(2)$. 
issue only when the first court has held the complaint to be admissible and, without rendering an interlocutory judgment to that effect, decided the case on the merits. ${ }^{123}$ The $O L G$, however, is unlikely to do so; rather, it will probably rule on this issue in the final judgment, unless it appears that the litigation on the subject matter will take a great amount of time, making it desirable to get an early binding decision on the admissibility issue. Under these circumstances, the $O L G$, if its interlocutory judgment is appealed, will in all likelihood await a decision by the $B C H$ on this issue. The test of urgency of the subject matter or of minute chances of a successful appeal, which is said to determine whether further hearings shall be ordered, ${ }^{124}$ will hardly ever be met. For these reasons it is not of great practical significance that an interlocutory order by the $O L G$, in the exceptional case where it is granted, cannot be attacked by limited appeal.

\section{The Basis-of-Recovery Exception}

Where an action is brought for an amount of money including, but not limited to, money damages, and the basis, as well as the amount, of recovery is in controversy, a German court is enabled by section 304(1) of the Code of Civil Procedure to render a judgment on the basis-of-recovery issue only. This presupposes that the plaintiff's claim is not held to be entirely without basis; if no basis for the claim is found, the action must be dismissed ${ }^{125}$ by a judgment, which is by its very terms a final decision, since it leaves nothing for the court to decide. If, however, part of the basis for plaintiff's claim is held to be well-founded, whereas another part is not, section 304(1) applies so long as the claimed amount of recovery could be justified on either basis. Should the well-founded ground fail to support recovery of the entire amount claimed, a final judgment dismissing the complaint with respect to the excess must be rendered. This judgment can be coupled with a judgment in accordance with section $304(1)$ respecting that part of the basis of recovery which the court regards as valid. ${ }^{126}$

An example in point would be an action for damages based both on breach of contract and on the commission of a tort. To the extent that plaintiff claims damages for pain and suffering (which under German law he must specify as an item separate from actual damages) and the court concludes there is a basis for recovery in contract, but not in tort, a final judgment dismissing the action in the amount claimed for pain and suffering must be forthcoming. The court in its discretion may enter a further judgment (often included in a single document with the first one) upholding plaintiff's cause of action in contract so far as the basis of recovery is concerned; but the amount of recovery is, by hypothesis, not yet ripe for decision. ${ }^{127}$

123. See id. $\$ 303$

124. See R. ZölLER, supra note $117, \S 280$ annot. III.

125. See id. $\$ 304$ annot. III 1 ; H. ThOMAs \& H. Putzo, Zivilprozessordnung, $\$ 304$ annot. 1 (12th ed. 1982).

126. 2 F. Stein \& M. Jonas, Zivilprozessordnung, $\$ 304$ annot. I 2 b $\alpha$ (19th ed. 1972); R ZOLLER, supra note $117, \S 304$ annot. II 5.

127. For a detailed discussion of this point, see Schneider, Probleme des Crundurteils in der Praxis (II), 1978 MonatsSChRIFT FUR DEUTSChES RECht 705, 793. 
A judgment rendered in conformity with section 304(1) and upholding the basis of recovery, either in whole or in part, is subject to an attack by appeal, even though it is clearly not a final judgment. This follows from section 304(2), which provides that the judgment "is to be regarded" for purposes of review as a final judgment. Here, too, one encounters the legislative technique of fiction. The Code further provides in section 304(2) that the court can grant a motion for further hearings insofar as it has held the basis of plaintiff's claim to be well-founded. This rule is analogous to that embodied in section 280(2) regarding interlocutory judgments on the admissibility of the complaint; consequently, the above comments on that rule apply in most part here as well. ${ }^{128}$ Courts, however, are generally more inclined to continue with a case after rendering an interlocutory judgment on the basis-of-recovery issue than after rendering such a judgment on the admissibility of the complaint. In conformity with this tendency of the courts, commentators and other writers advocate a standard for determining whether to grant a motion for further hearings under section 304(2), that is less restrictive than that advanced for the same determination under section 280(2).

The reasons for these variations in approach are obscure. Policy considerations seem to require application of a similar or even identical test in both instances. The general rule should be that, absent exceptionally compelling interests on the part of the plaintiff or an exceptionally weak position on the part of the defendant regarding his appeal, the lower court should not continue and possibly terminate the case on the merits, or on the amount of recovery, while the appeal is still pending. A more lenient position in this respect is at odds with the alleged purpose of rules allowing an interlocutory appeal. The investment of time, energy, and money necessary to decide a case on the merits or on the amount of recovery would not thereby be avoided. It may indeed turn out to be wasteful, if upon appeal the interlocutory judgment is reversed, so that defendant wins regardless of the court's decision on the merits or the amount of recovery.

On a doctrinal, but at the same time very practical level, it must be asked what happens to a final judgment in favor of plaintiff resulting from the further hearing and, possibly, the taking of evidence in the lower court, once the appeal is decided in defendant's favor and the appellate court's judgment is not subject to further review. While there is no case directly in point, writers today agree that the final judgment of the lower court under such circumstances loses its effectiveness and the appellate court's decision prevails; this result obtains even where the final judgment has not been appealed and the period for filing an appeal has expired so that, on its face, this judgment is res judicata. ${ }^{129}$ Arguably, the lower court's final judgment should be viewed as conditional. ${ }^{130}$ Even though the terms of the implied condition are not clearly spelled out in the literature, it is fairly obvious that the continued existence of the interlocutory judgment is regarded as the cru-

128. See supra text accompanying notes 116-24.

129. F. STEIN \& M. Jonas, supra note $126, \S 304$ annot. III 4; L. RosenberG \& K. H. SChWAB, supra note 92, § 55 III 3b; Schiedermaier, Die Wirkung der Anfechtung uon Zwischenurleilen nach $\$ \$ 275,30+Z P O$ auf das Endurteil, 1961 JURISTICHE SCHULUNG 212.

130. See L. ROSENBERC \& K.H. SCHWAB, supra note 92, § 55 III 3b; Schiedermaier, supra note 129, at 214. 
cial factor. ${ }^{131}$ Furthermore, the argument continues, since the lower court's final judgment is deprived of its effects automatically, the court need not reverse it. ${ }^{132}$ Such reversal is said to be not only unnecessary but even precluded because section 318 of the Code of Civil Procedure makes every judgment, interlocutory or final, binding upon the court from which it originated. ${ }^{133}$ This, however, is a doubtful analysis. The defendant's interests would be better protected if the continued appearance of an enforceable judgment could be removed.

The rule in section 318 is not without exceptions. In the case of a setoff, ${ }^{134}$ section 302(4) authorizes the court, and in fact makes it mandatory upon the court, to reverse its interlocutory judgment for plaintiff once it finds the setoff to have been effective. ${ }^{135}$ Since the interlocutory judgment based on section 302 is viewed as a conditional decision, just as much as is the final judgment rendered during the pendency of an interlocutory appeal based on section 304, a very good argument can be made by analogy in favor of a reversal which would protect the defendant's interests more effectively and become a matter of public record. This analysis would conform to the civilian tradition of Code interpretations.

A second and final point concerns the overall experience with a rule like section 304 , which allows an appealable interlocutory judgment on the issue of the basis of recovery, as distinguished from the amount of recovery. The rule is said to serve the purpose of accelerating litigation. ${ }^{136}$ This objective is probably attained at times, but the courts are criticized not infrequently, because the application of the rule tends to increase the problems and the expenses involved in litigation. ${ }^{137}$ The $B G H$ also admonishes the lower courts not to lose sight of the principal policy underlying the rule and not to apply it where legitimate interests of a party advise against such application. ${ }^{138}$ Arguably, however, it is not solely the courts' fault if the rule does not yield satisfactory results in a great number of cases. The abundance of appellate cases interpreting section 304 suggests that it is much harder to apply it consistently and in a coherent fashion than the seemingly simple dichotomy underlying it (basis versus amount of recovery) reveals. ${ }^{139}$ An inordinate amount of case law evolved from the continuous efforts of the $B G H$ and the intermediate appellate courts $(O L G)$ to demarcate the two elements of this dichotomy sufficiently so as to prevent the lower courts from going astray too frequently. ${ }^{140}$ Yet the consistently large number of reversals on this issue compels the conclusion that these efforts have met with little success.

Possibly, this failure must be attributed to conceptual difficulties inherent in

131. L. Rosenberc \& K.H. SCHWAB, supra note 92, §55 III 3b; Schiedermaier, supra note 129, at 214.

132. L. ROSENBERG \& K.H. SCHWAB, supra note 92, \$ 55 III 3b; Schiedermaier, supra note 129, at 214.

133. ZPO § 318 ; see Schiedermaier, supra note 129, at $214 \mathrm{n} .11$; see also F. STEIN \& M. JONAS, supra note $126, \S 304$ annot. III 4 (somewhat inconclusive on this point).

134. ZPO § 302(4).

135. See supra text accompanying notes 93-99.

136. See R. ZölLLR, supra note 117, § 304 annot. I.

137. Id.

138. See cases cited by BAUMBACH, supra note $105, \S 304$ annot. I.

139. See id. $\S 304$ annots. 3 I B, C, D; R. ZölleR, supra note 117, § 304 annots. II 4, 5, 6 .

140. BAUMBACH, supra note $105, \S 304$ annots. 3 I B, C, D; R. ZÖLLER, supra note $117, \S 304$ annots. II $4,5,6$. 
the dichotomy itself. Does, for example, a defense of comparative negligence (available under German law in tort and contract cases) affect the basis in terms of a percentage reduction or only the amount of recovery? What about a partial assignment of plaintiff's rights or a partial attachment or subrogation by operation of law? These and many other questions regarding classification of particular legal situations in view of the distinction between the basis and the amount of recovery have troubled the courts enormously. ${ }^{141}$ The time, energy, and expenditure devoted to the resolution of these questions in many cases probably exceeds by far the potential benefits from the rule embodied in section 304 of the German Code of Civil Procedure.

Moreover, the case law requires the lower court to consider the measure-ofrecovery issues, at least summarily, before it renders an interlocutory judgment on the basis-of-recovery issue. ${ }^{142}$ This requirement is designed to protect the defendant from irreparable harm which he may incur if he is defeated on an interlocutory appeal and therefore bears considerable cost (including his opponent's attorney fees under German fee-shifting rules), only to find out a little later that the amount of recovery is negligible or indeed nil. Under these circumstances, defendant's expenditures would be much less (or could, in a case of dismissal by virtue of the final judgment, be completely shifted to the plaintiff) had there been no interlocutory judgment. 143

The summary review of measure-of-recovery issues thus required hardly increases the speed of the proceedings. On the other hand, from the plaintiff's perspective there are serious potential disadvantages involved in an interlocutory judgment based on section 304. Such a judgment is by its very terms incapable of enforcement, whereas a final judgment determining not only the basis but also the amount of recovery can in most instances be executed even while an appeal is pending. In order to prevent execution, defendant must at least provide a security bond. ${ }^{144}$ The plaintiff's obtaining these benefits of a final judgment can be delayed substantially, perhaps by as much as several years, by the defendant's appeal (Berufung), and possibly a second appeal (Revision), from an interlocutory judgment, provided the litigation on the amount of recovery in the lower court does not proceed during the pendency of the appeal(s). Arguably, this accounts for the courts' tendency to grant motions for further hearings on the measure of recovery in an effort to mitigate the plaintiff's plight. In sum, the experience with

141. A telling statement by courts and writers is that the line between the basis and the amount of recovery must be drawn according to procedural economy and practical efficiency. When most recent Supreme Court cases sum up decades of judicial efforts to provide more reliable guidance concerning this distinction in this way, it is not unfair to interpret such statements as almost unlimited admissions of failure. See BAUMBACH, supra note 105, § 304 annot. 3 (and cases cited therein).

142. Judgment of Nov. 4, 1960, BGH, 74 ZEITSCHRIrT für Zivilprozess 279, 280 (1961). For additional cases, see H. Thomas \& H. PuTzO, supra note $125, \S 304$ annot. 3B; F. STEIN \& M. Jonas, supra note $126, \S 304$ annot. I 2 B $\beta, \gamma$.

143. The $B G H$ has held that there is no exception to the rule requiring a defeated appellant to bear all the expenses (including his opponent's attorney fees) of an interlocutory appeal, even if the final judgment is in his favor. In doing so, the court admitted that the results may be harsh. See Judgment of May 29 , 1956, 20 BGHZ 397 (1956).

144. ZPO $\$ 712$. 
section 304 of the German Code of Civil Procedure does not lend support to advocates of this kind of a departure from the final judgment principle.

\section{E. The Limited Appeals Exception}

A general outline of this type of review was provided in Part II of this article. ${ }^{145}$ The basic rule, stated in section 567(1) of the Code of Civil Procedure, is that a decision can be challenged by limited appeal in all instances specifically provided for in the Code. ${ }^{146}$ If there is any rational principle that has guided the legislature in making or not making such specific provision and in deciding whether to require a prompt limited appeal or to permit a simple limited appeal, it has obviously remained unintelligible to the lawyers who, in their respective roles as judges or authors, have failed to discern a common thread running through the numerous Code sections allowing a limited appeal. In sharp contrast with the general belief that codes in civil law countries are always systematically organized and based on rational principles closely adhered to, the matter here under consideration furnishes a prime example of haphazard legislative patchwork. This is not to say that codes of civil law countries generally fail to meet the standard of well-structured, principled legislation, but such failure can, on occasion, be observed.

In the absence of an intelligible principle expressing overarching policy considerations, it is impossible to convey to the reader an all-inclusive general idea of the kinds of situations in which the German Code of Civil Procedure has created further specific exceptions to the final judgment rule by permitting limited appeal. However, a few examples can be furnished.

If a motion to disqualify a judge is denied, the order can be challenged by a prompt limited appeal under section 46(2) of the Code. Consequently, a party desiring to attack such order must avail himself of the right to a limited appeal. Ordinarily, of course, under section 512, decisions preceding a final judgment can be reviewed upon appeal taken from that judgment. ${ }^{147}$ That section, however, with respect to a first appeal (Berufung), excludes those interlocutory decisions which are subject to an attack by limited appeal. This exception applies to all decisions preceding a final judgment which are subject to a limited appeal. Thus, the party aggrieved by such a decision has no choice but to bring the limited appeal, or else to forego the right to challenge the decision.

A third party who finds it advisable to intervene in a pending case in support of one of the parties to this case may do so according to sections 67 and 71 (1) of the Code, provided he or she can make a prima facie showing of a "lawful interest" (rechtliches Interesse) in the victory of the party to be supported. ${ }^{148} \mathrm{~A}$ motion to deny the intervention must be decided upon not by an order, but by a judgment, termed a Zwischenurteil (interlocutory judgment), which is reviewable by prompt limited appeal under section 71(2). ${ }^{149}$ Arguably, a decision denying the interven-

145. See supra text accompanying notes $61-70$.

146. ZPO $\S 567(1)$.

147. ZPO § 512; see supra text accompanying note 107 .

148. ZPO $\S \S 67,71(1)$.

149. Id. $\S 71(2)$. 
tion might even be viewed as a final judgment because it purports to terminate the case in this court vis-a-vis the third party; and yet, strangely, a prompt limited appeal instead of a regular appeal is provided. ${ }^{150}$

A witness who is summoned by the court to appear at a hearing (the standard procedure under German law) and does not comply will have costs and a fine assessed against him by court order. Pursuant to section $380(3)$, the witness may challenge such an order by a simple limited appeal. ${ }^{151}$ If a witness refuses to testify, invoking any of the several grounds for a privilege, ${ }^{152}$ the court must decide this issue by an interlocutory judgment reviewable under section 387 (3) by prompt limited appeal. ${ }^{153}$ Should the witness refuse to testify, either without giving a reason or after an alleged privilege has been denied by a judgment which has become res judicata, then costs and a fine will be assessed against him not by a judgment, but by an order which under section $390(3)$ is subject to a simple limited appeal. ${ }^{154}$

These examples may suffice to illustrate the confusion resulting from that branch of section 567 of the German Code of Civil Procedure which allows a limited appeal in all instances for which specific provisions are made. In addition, the second branch of this basic rule supplies a more general test for determining whether a decision can be attacked by limited appeal. Under this test, any decision that denies a motion concerning the proceedings and that does not require an oral hearing is subject to review, except a decision relating to costs, fees, and expenses where the amount in controversy on review does not exceed $100 \mathrm{DM}$ (currently the equivalent of about thirty-five dollars). ${ }^{155}$ Decisions of the $O L G$, however, are generally not reviewable by limited appeal. ${ }^{156}$

Despite its more general terms, the second branch of the rule in section 567 also necessitates a case-by-case determination of the availability of a limited appeal; a procedural ruling by the court denying a motion can be attacked in this fashion only where the court's decision did not require an oral hearing. It is immaterial whether an oral hearing was in fact conducted. The only crucial factor on which this test turns is the applicability of any of the statutory rules in the Code of Civil Procedure which dispense with the requirement of an oral hearing as a prerequisite for the particular decision. ${ }^{157}$ What is the policy underlying the use of the absence of a mandatory oral hearing as the basis for deciding that a decision is reviewable by limited appeal? It is usually, and perhaps thoughtlessly, stated in

150. There are a number of differences between these means of review, of which two are particularly significant. The period for filing a prompt limited appeal is two weeks. ZPO $\S 712$. The period for an appeal (Berufung or Revision) is one month. ZPO $\S \S 516,522$. The review proceedings in the case of a limited appeal are very informal with no right to an oral hearing granted by the Code, whereas in the proceedings on ordinary appeal, oral hearings are strictly required. Compare ZPO $\$ \S 567-76$ with ZPO $\S \S 520,555$.

151. ZPO § 380(3).

152. See ZPO §§ 383, 384.

153. Id. $\S 387(3)$.

154. Id. $\$ 390(3)$.

155. Id. $\S 567(2)$.

156. ZPO $\S 567(3)$. The three exceptions to the rule enumerated in section $567(3)$ need not be discussed for present purposes; these exceptions have no immediate bearing on the topic at hand.

157. See L. ROSEnberg \& K.H. SChWab, supra note 92, § 144 II 2 a. 
terms of sifting out less important decisions for this mode of review. ${ }^{158}$ There is little or no discussion in German legal literature that attempts to square this policy with the purposes of the final judgment principle expressed in sections 511 and 545 of the Code of Civil Procedure. ${ }^{159}$ Obviously, these purposes are better served by a rule which permits review of less important decisions preceding the final judgment only on appeal from the final judgment. At present, however, German law is to the contrary.

This can give rise to startling consequences. Sometimes a limited appeal may be available from an interlocutory decision, even though the final judgment in that case is not subject to review by appeal. For example, judgments of the $L G$ upon appeal from the $A G$ are not reviewable at all; ${ }^{160}$ nonetheless, the rules in both branches of section 567 open avenues for review of less important decisions of the $L G$, rendered prior to its final judgment as an appellate court. This is paradoxical, but German writers and courts, while carving out certain exceptions, conclude from an analysis of the Code of Civil Procedure and other statutes that the Code does not embrace a general principle by which the power to review an interlocutory decision cannot be vested in a court that is without power to review a final judgment in the same case. ${ }^{161}$

The so-called exceptions in favor of coordinating the power of interlocutory review with the power to review final decisions may not be in every respect genuine exceptions. To be sure, courts have held and writers have argued, in defense of such exceptions, that interlocutory review in a case where the final judgment is not reviewable does not permit the higher court to express and substitute its views for those of the lower court regarding the merits of the case. ${ }^{162}$ This is truly a judicial gloss on the Code in the direction of harmonizing the availability of interlocutory review with the nonreviewability of a final decision in the same case. In a second category of alleged exceptions, however, are orders accompanying a nonreviewable final judgment and concerning such issues as the execution of the judgment or the correction of the text of the judgment because of errors in computation and the like. ${ }^{163} \mathrm{~A}$ third group is made up of orders issued in cases terminated without a judgment on the merits rendered by the same court-for example, where the case has become moot during pendency on appeal to the $L G$, and, upon motions by the parties, this court decides (pursuant to section 91a. ${ }^{164}$ ) who must bear the costs, including attorney fees. ${ }^{165}$ Also included in this group

158. See L. ROSENBERG \& K.H. SCHWAB, supra note $92, \S 144$ I; BaUMBACH, supra note 105 , survey preceding $\S 567$ annot. 1.

159. ZPO $\S \S 511,545$; see supra text accompanying notes 81-86.

160. See supra text accompanying notes $48-58$.

161. Sec L. Rosenberg \& K.H. SChWab, supra note 92, § 148 III2; Baumbach, supra note 105, §567 annot. 5 .

162. See L. Rosenberg \& K.H. SChwab, supra note 92, § 148 III 2 (and cases cited therein); BaUMBACH, supra note 105, $\$ 567$ annot. 5 (and cases cited therein).

163. L. Rosenberg \& K.H. SchWAB, supra note 92, § 148 III 2 (and cases cited therein); BaUmbach, supro note 105, $\S 567$ annot. 5 (and cases cited therein).

164. ZPO § $91 \mathrm{a}$.

165. L. ROSENBERG \& K.H. SCHWAB, supra note 92, § 148 III 2 (and cases cited therein); BAUMBACH, supra note 105, $\$ 567$ annot. 5 (and cases cited therein). 
are appellate decisions by the $L G$ in the form of an order, not a judgment, denying a preliminary injunction.

The second and the third group of cases do not involve interlocutory orders insofar as, at the time they are issued, the case as a whole has come, or is coming, to a close. ${ }^{166}$ To this extent, the orders whose reviewability is at stake are final in character, leaving nothing else of which the court can dispose. Consequently, the courts denying limited appeal in these instances, given the language of section 567 coupled with more specific rules of the Code of Civil Procedure, are not confronted with the task of coordinating two avenues of review potentially available in the same case, one designed for final judgments, the other for interlocutory decisions. They merely curtail review by limited appeal in situations where this is the only possible remaining means of review. In doing so, they take account of the fact that the orders in question supplement a final judgment (effecting its execution or correction) or take the place of such judgment (deciding the cost issue after a case became moot). From this it is apparently concluded that no review of these orders must be permitted where there is no review of the final judgment of which the order is a part or for which it is a substitute. This is a far cry from bringing interlocutory appeals in line with appeals from a possible subsequent judgment.

The foregoing discussion underscores the point made in Part II of this article, that limited appeal (Beschwerde) must not be equated with, and the German term must not be translated as, "interlocutory appeal" because in certain instances this means of review can be used to control final decisions. ${ }^{167}$ Thus if the $A G$, or the $L G$ in its role as a court of first instance, decides on costs (including attorney fees) after the parties have stated that the case was moot and applied for an order on the cost issue, the order can be challenged by limited appeal pursuant to section 91a. The decision thus challenged is final in that it disposes of the case on the merits and leaves no question open for judicial determination. By allowing an adversely affected party to challenge the order through limited appeal, the Code in this situation does not deviate from the finality principle. By the same token, the courts do not vindicate this principle when they disallow limited appeals from cost orders of the $L G$ in an appellate case. Rather, this case law enforces treatment equal to that given the standard ruling on costs included in a final appellate judgment of the $L G$, which is not subject to an appeal. The rationale of the latter approach is that an isolated decision on costs which terminates the proceedings without a judgment, should not enjoy a higher degree of reviewability than the same kind of decision embodied in a final judgment.

In the last analysis, the rules permitting review of interlocutory decisions by way of limited appeal cannot be reconciled with the final judgment principle and its policy. The ensuing lack of consistency in the German system of appellate review can probably be attributed to historical factors predating the Code of Civil Procedure. The predecessor of limited appeal in the pre-Code era (the modern

166. This applies to all situations in these two categories except for appellate orders denying preliminary injunctions.

167. See supra p. 41. 
Code of Civil Procedure was enacted in $1877 .{ }^{168}$ ) was the querela simplex which, in turn, seems to have originated from canon law procedure. It is tentatively submitted that, since the final judgment rule was alien to this law just as it was to equity, the problem of reconciling the predecessor of limited appeal with a finality requirement for appeals did not arise under canon law. When the final judgment rule became a part of more modern civil procedure and was eventually embodied in the 1877 Code, the querela simplex was preserved in the form of limited appeal (Beschwerde). It is very likely that the limited appeal became a part of the modern system without its reevaluation in view of the changed system of appellate review based on the finality principle.

\section{F. The Certified Question Exception}

As pointed out in Part II of this article, the certification of a legal question to a higher court is not infrequently required or at least authorized by German law. ${ }^{169}$ To the extent that this device is provided for in a court whose final judgment is not subject to an appeal, such as appellate judgments of the $L G$, it can be argued that allowing certification does not constitute a departure from the finality requirement. This argument assumes that the finality requirement is merely concerned with the proper timing (the "when"), not with the feasibility (the "if") of appellate review. Arguably, with this assumption as a starting point, certification of questions of law to a higher court that has no jurisdiction upon appeal because the final judgment of the lower court will be immune from appellate review does not encroach on the policy supporting the finality requirement. The parties cannot use certification for purposes of delay, since only the lower court, and not the parties, decides whether there will be certification. ${ }^{170}$ Furthermore, the upper court's resources are not tapped more than once, as may happen where interlocutory as well as final decisions are appealable.

From a somewhat broader perspective, a rule denying, with respect to certain judgments, any review by appeal is typically based on policies which overlap with those behind the finality requirement. Where the "if" of an appeal is answered in the negative by the Code or a statute, the principal purpose is likely to be the protection of appellate courts from overcrowded dockets. Thus, the denial of appellate review by the legislature in certain cases seeks to reduce the strains upon the appellate system, just as does the requirement of a final judgment as a prerequisite for review. However, a rule affording a judgment absolute finality and a rule requiring finality before appeal—notwithstanding the large measure of identity of purpose and semantic affinity between the two-have, in effect, completely different qualities.

Even so, certification can be a questionable device in several respects. First and foremost, the parties are not before the judicial body to which the legal question is certified, so that no exchange of arguments between them and no communication with the judges is possible. Also, these judges do not always benefit from a com-

168. See supra note 6 .

169. See supra text accompanying notes 71-73.

170. See FGG § 28; GVERFG § 136; GG art. 100(1), (2). 
plete record below, since certification may occur before all the issues have been fully litigated. ${ }^{171}$ Finally, it is possible that the certified question can become irrelevant in the course of further litigation, so that the certification procedure would turn out to be wasteful in the eyes of at least one of the parties. With respect to the last two points, which are closely related to each other, the problems inherent in the certification device are similar to those arising from interlocutory appeals. They stem from the fact that litigation in the court below has not yet come to a close. In this respect, some of the reasons supporting the finality principle also provide grounds for criticism of extremely frequent legislative use of the certification device.

\section{Conclusions}

The foregoing discussion makes clear that the German law relating to the final judgment principle is no less confusing and bewildering than the law of federal civil appellate jurisdiction in the United States. The principle of finality is riddled with exceptions in both systems.

These exceptions are sometimes so limited in scope that their practical significance does not warrant a departure from the final judgment principle at the risk of creating unnecessarily complicated procedural situations. This would seem to be true of the setoff exception in section 302 of the Code of Civil Procedure. ${ }^{172}$

Sometimes an exception is expressed in statutory language which seems to invite judicial manipulation and thus reveals a lack of sufficient legislative awareness of the problems at hand. This is apparent in section 280 of the Code of Civil Procedure, which on its face makes an interlocutory appeal turn on whether the court in its discretion conducted a special hearing before it ruled on the admissibility issue. ${ }^{173}$

On the other hand, the basis-of-recovery exception in section 304 of the Code of Civil Procedure suffers not from poor draftsmanship, but from serious conceptual problems inherent in the distinction between the basis and the amount of recovery. The significant expenditure of judicial efforts at clarification of this distinction appears to be out of proportion to the benefits derived from the exception. ${ }^{174}$

The device of limited appeal, yet another exception to the finality requirement, is a remnant from an earlier period in the history of civil procedure. To this day, more than one hundred years after the German Code of Civil Procedure was enacted, the role of limited appeal in an appellate system based on the finality principle has not been redefined. Currently, there remains the paradox that less important interlocutory decisions in the form of orders are subject to review by

171. See FGG $\S 28$; GVERG $\S 136$; GG art. 100(1), (2). These rules do not specify any point during the proceedings at which the court may or may not exercise its power to order the certification of a question.

172. See supra pp. 45-46.

173. See supra text accompanying notes 111-13.

174. See supra text accompanying notes 138-41. 
limited appeal, while interlocutory judgments on matters of procedure (with the exception of those on the admissibility of the complaint under section 280), are not, pursuant to section 303 of the Code of Civil Procedure, separately appealable. ${ }^{175}$

Certification of a legal question does not, strictly speaking, constitute a departure from the finality principle in those cases where the final judgment of the certifying court is not reviewable. Rather, it functions to some degree as a substitute for an appeal; nonetheless, the use of this device produces certain problems which are also associated with interlocutory appeals. ${ }^{176}$

A complete overhaul of the German system of civil appellate jurisdiction seems advisable. The present system can best be characterized as a glaring example of how not to do it.

175. See supra text accompanying notes 160-61. This conclusion is compelled by a comparison of section 280 with section 303 .

176. See supra pp. 57-58. 